\title{
Identitas Budaya Masyarakat Kota: Teater Tradisi di Kota Surabaya pada Awal Abad XX
}

Alamat korespondensi: sambaskoro@gmail.com

Diterima/ Received:

21 Maret 2019

Disetujui / Accepted:

3 Juli 2019

\author{
Samidi \\ Departemen Ilmu Sejarah, Fakultas Ilmu Budaya, \\ Universitas Airlangga
}

\begin{abstract}
This study examines why does Ludruk represent the cultural identity of the people of Surabaya? How does society appreciate the traditional theater, especially in Ludruk in their daily practice? The purpose of this article explains the historical reality of Ludruk art that serves as entertainment and cultural identity. This article uses the historical method by relying on historical sources. The result shows that theater traditions that existed and famous in Surabaya at the beginning of the 20th century were Comedy Stambul, Wayang Wong, and Ludruk, then appeared Kethoprak in the late 1930s. The appearance of this theater has been adapted to the tastes of the support community. Comedy Stambul is a theater that originated in India, then spread to Southeast Asia. Comedy Stambul is considered as a hybrid art because it comes from a blend of local cultural elements, while Wayang Wong, Ludruk, and Kethoprak an original art derived from customs and local values. Theater that represents the cultural identity of the people of Surabaya is Ludruk.
\end{abstract}

Keywords: Cultural Identity; Performing Arts; Theater Tradition; Ludruk.

Abstrak
Kajian ini menganalisis mengapa kesenian Ludruk merepresentasikan identitas
budaya masyarakat Kota Surabaya? Bagaimana masyarakat mengapresiasi teater
tradisi terutama pada kesenian Ludruk dalam praktik keseharian mereka? Tujuan
artikel ini menjelaskan realitas historis kesenian Ludruk yang berfungsi sebagai
hiburan dan identitas budaya. Artikel ini disusun menggunakan metode sejarah
dengan mengandalkan sumber-sumber sejarah. Hasil menunjukkan bahwa teater
tradisi yang eksis dan populer di Surabaya pada awal abad ke-20 adalah Komedi
Stambul, Wayang Wong, dan Ludruk, kemudian muncul Kethoprak pada akhir 1930-
an. Tampilan teater ini telah disesuaikan dengan selera masyarakat pendukung.
Komedi Stambul merupakan teater yang berasal dari India, kemudian menyebar
di Asia Tenggara. Komedi stambul dianggap sebagai kesenian campuran karena
dihasilkan dari perpaduan unsur-unsur budaya lokal. Sementara itu, Wayang
Wong, Ludruk, dan Kethoprak merupakan kesenian asli yang bersumber dari adat-
istiadat dan nilai-nilai lokal. Berdasar ketiga teater tradisi ini, teater yang
merepresentasikan identitas budaya masyarakat Kota Surabaya adalah Ludruk.

Kata Kunci: Identitas Budaya; Seni Pertunjukan; Teater Tradisi; Ludruk. 


\section{Pendahuluan}

Teater komersial mulai dikenal oleh masyarakat Surabaya ketika diselenggarakan pertunjukan drama Eropa pada pertengahan abad ke-19 (von Faber, 1931, p. 339). Pendukung hiburan komersial datang dari kelas menengah kota yang mengalami peningkatan bersamaan dengan perkembangan perkebunan, perdagangan, dan industri. Kondisi ini diikuti oleh munculnya teater tradisi sebagai alternatif hiburan baru masyarakat kota. Selama paruh pertama abad ke-20, eksistensi teater tradisi menunjukkan popularitas dan masa kejayaan atau era keemasan, tetapi keadaan berbalik ketika budaya lokal berbenturan dengan budaya global pada akhir abad ke20. Gaya gerak sentrifugal budaya global didukung oleh percepatan jaringan komunikasi, informasi, teknologi, dan perdagangan, menimbulkan dampak percepatan perubahan sosial-budaya dan kejutan budaya. Ada dua fase yang dialami ketika berlangsung hubungan budaya lokal dan global, yakni fase homogenisasi dan hibriditasi (Pisani, 2004, p. 40).

Dampak yang ditimbulkan oleh fase globalisasi dapat mengancam keragaman budaya lokal atau sebaliknya membangkitkan usaha melawan penciptaan budaya global (Rosenmann, et al., 2016, p. 203). Akan tetapi, realitas eksistensi teater tradisi terhempas dalam gelombang homogenisasi. Strategi teater tradisi bertahan hidup pada akhir abad ke-20 ternyata tidak mampu menguatkan akar, sehingga masyarakat pendukung tidak antusias lagi terhadap hiburan ini. Paruh pertama abad ke-20 adalah waktu yang menunjukkan eksistensi teater tradisi menyatu dalam kehidupan seharihari masyarakat. Akhir abad ke-20 merupakan waktu yang menunjukkan titik balik yang mengarah pada penurunan, kemunduran, dan kurang menarik sebagai hiburan. Artikel ini tidak bermaksud menelaah pengaruh budaya global terhadap kemunduran teater rakyat, tetapi lebih ditekankan pada kajian popularitas teater tradisi yang merepresentasikan identitas budaya pada paruh pertama abad ke-20.

Menurut Brandon (2003), teater tradisi merupakan seni pertunjukan tradisional di Asia Tenggara yang terikat oleh faktor-faktor di luar kesenian, di antaranya perubahan sosial, ekonomi, dan politik. Faktor eksternal ini memengaruhi adaptasi dan perubahan kesenian. Soedarsono (2003, p. 12) menyatakan bahwa perkembangan seni pertunjukan dipengaruhi oleh faktor-faktor nonkesenian. Kajian yang dilakukan oleh Peacock (2005) terhadap kesenian Ludruk membuktikan adanya adaptasi kesenian Ludruk terhadap lingkungan sosial. Fungsi Ludruk tidak hanya sebagai hiburan belaka, tetapi juga sebagai perwujudan media komunikasi dan propaganda, ritus modernisasi, dan representasi kelas sosial.

Gagasan tentang pengaruh eksternal terhadap seni pertunjukan menunjukkan bahwa seni pertunjukan tradisional dikaji melalui pendekatan kontekstual. Pendekatan kontekstual memfokuskan pada konstelasi sejumlah elemen, bagian, dan fenomena, yang berhubungan dengan kesenian. Seni pertunjukan juga dapat dikaji dengan pendekatan tekstual. Pendekatan tekstual meliputi telaah simbolik, struktural, dan kaidah-kaidah kesenian (Ahimsa-Putra, 2000, p. 399). Artikel ini menggunakan pendekatan kontekstual untuk menjelaskan eksistensi teater tradisi dengan fokus kajian pada kesenian Ludruk pada awal sampai pertengahan abad ke-20. Batasan 
waktu menegaskan perspektif historis yang implikasinya tampak pada pemilihan sumber sejarah dari data tertulis sezaman khususnya koran dan majalah.

\section{Metode}

Artikel ini merupakan hasil dari penelitian sejarah. Karya sejarah adalah tulisan tentang peristiwa dan realitas yang terjadi pada masa lampau. Mengetahui realitas dan sesuatu yang terjadi dengan durasi satu abad yang lalu, dalam konteks ini tulisan ini adalah pada awal abad ke-20, penjelasan sejarah mengandalkan berbagai bukti yang tercetak terutama terbitan sezaman, yakni koran dan majalah. Data cetak untuk penelitian ini diperoleh dari dokumen, laporan, majalah, dan koran yang dapat diklasifikasi berdasar (1) sumber resmi pemerintah kolonial, (2) terbitan sezaman, (3) laporan. Data ini diperoleh melalui penelusuran di kantor arsip dan perpustakaan, seperti Kota Surabaya (di antaranya Arsip Kota Surabaya, Arsip Provinsi Jawa Timur, dan Perpustakaan), Jakarta (Perpustakaan Nasional), Yogyakarta (Perpustakaan Provinsi khususnya pada koleksi langka), dan Surakarta (Museum Pers). Sumber resmi pemerintah yang terdapat di kantor Arsip Kota Surabaya dan Provinsi Jawa Timur berupa bundel-bundel arsip, sedangkan sumber terbitan sezaman dilacak di ruang koleksi koran di perpustakaan-perpustakaan terutama Perpustakaan Provinsi Yogyakarta, Museum Pers Surakarta, dan Perpustakaan Nasional Jakarta. Jenis koran yang sudah dilacak adalah Bintang Hindia, Bintang Soerabaia, Pewarta Soerabaia, De Indische Courant, Soeara Asia, Suara Masjarakat, Trompet Masjarakat, Java Post, Perdamaian, dan Obor Surabaja. Majalah dan terbitan berkala yang dilacak, antara lain Medan Prijaji, Viribus Unitis, Panjebar Semangat, Pandji Poestaka, dan Mutiara.

Data tersebut diklasifikasi, diverifikasi, dan dianalisis untuk kepentingan penulisan sejarah (artikel sejarah). Semua data yang diperoleh diverifikasi dan dikritik terutama mengenai validitas berita melalui pengecekan dan membandingkan beberapa berita yang serupa. Hal ini untuk meminimalkan kesalahan pada data penelitian. Analisis data dilakukan sejak pengumpulan dilakukan sampai penulisan berakhir. Teknik analisis data disesuaikan dengan jenis data yang dicapai, yaitu (1) teknik analisis historis (perkembangan, perubahan, dan fenomena) yang ditujukan untuk memahami dan mendeskripsikan sejarah teater tradisi.

\section{Kesenian Ludruk Menjadi Pertunjukan Komersial}

Kesenian Ludruk lahir melalui modifikasi berbagai unsur teater komersial yang lebih dahulu muncul pada akhir abad ke-19. Perubahan kesenian Ludruk dari permainan rakyat ke seni pertunjukan komersial merupakan bentuk kreativitas masyarakat menanggapi kebutuhan hiburan masyarakat. Dasar pembentukan kesenian Ludruk disesuaikan dengan unsur-unsur dan nilai-nilai budaya lokal. Hal ini menunjukkan bahwa Ludruk berasal dari proses penciptaan, pendukungan, pemeliharaan, dan pengembangan, yang dilakukan oleh masyarakat lokal. Kesenian tidak pernah berdiri lepas dari masyarakat (Kayam, 1981, pp. 38-39). 
Kesenian Ludruk pada awal abad ke-19 bukan sebagai genre kesenian, tetapi bagian adat-istiadat yang diperagakan layaknya pertunjukan yang mengandung unsur magis. Hal ini diketahui dari karya Thomas Stamford Raffles (1811-1816), History of Java, sebagian isinya menjelaskan mengenai kesenian yang digemari masyarakat di Jawa, tetapi buku ini tidak mencantumkan Ludruk (Raffles, 2008, pp. 230-239). Perkembangan Ludruk menjadi genre kesenian dimulai dari Bandan, Lerok, dan Besutan. Permainan masih mempertontonkan kesaktian yang menyerupai sulap (Anonim, 1953, p. 850). Perkembangan Ludruk dimulai pada awal abad ke-20, ketika Lerok melakukan improvisasi sebagai seni pertunjukan. Upaya mengubah permainan dipengaruhi oleh popularitas teater komersial Komedi Stambul dan Wayang Wong. Pada dekade pertama abad ke-20, masyarakat mengenal istilah baru sebagai ganti dari Lerok, yakni Besutan atau Loedroek. Istilah ini muncul dalam pemberitaan koran yang terbit di Kota Surabaya pada awal abad ke-20 Pentas Besutan atau Loedroek masih bernuansa magis meskipun menyertakan unsur cerita dan drama (Bintang Soerabaia, 24 Mei 1904).

Pertunjukan Besutan berlangsung pada 1911 sampai 1931 (Pewarta Soerabaia, 14 Maret 1953). Besutan berubah ketika telah memiliki struktur pentas, seperti tari ngremo, kidungan, repertoar (cerita), dan dhagelan. Meskipun telah mengadopsi unsur-unsur drama, dialog dalam pertunjukan masih disampaikan secara spontan tanpa struktur utuh. Cerita mengisahkan peristiwa yang terjadi dalam kehidupan sehari-hari. Unsurunsur teater ini terus dikembangkan hingga mengubah struktur pentas Besutan. Pada dekade ketiga abad ke-20, istilah dan permainan Besutan yang bernuansa magis dapat dipastikan telah berubah menjadi Ludruk Sandiwara, yaitu bentuk pertunjukan teater komersial yang sebagian besar unsur-unsurnya bersumber dari perangkat dan nilainilai lokal (Obor Surabaja, 8 Januari 1952).

\section{Pertunjukan Komersial Pendahulu Ludruk: Komedi Stambul dan Wayang Wong}

Seni pertunjukan komersial di Kota Surabaya diawali oleh drama Eropa dan konser musik klasik dengan instrumen, seperti biola, piano, dan selo, yang dimainkan oleh seniman berkebangsaan Eropa pada pertengahan abad ke-19. Kelompok musik dan drama datang dari Italia dan Prancis, seperti Cagli, Balsofiore, Pompei, Torsoni, dan Van Kinsbergen (von Faber, 1931, pp. 338-340). Hiburan ini hanya dinikmati oleh golongan Eropa. Hal ini menstimulasi kelahiran Toneel Melayu atau Komedi Stambul pada akhir abad ke-19. Karakteristik musik digabung dari beberapa instrumen, seperti kroncong, gambang kromong, dan gamelan, sedangkan repertoar mengikuti cerita Arab dan Melayu. Beberapa perlengkapan pentas juga meniru drama model Eropa, misalnya panggung, kostum, pencahayaan, tiket, layar bergambar, poster, naskah, dan tiket. Penggabungan beberapa unsur kesenian menyebabkan Komedi Stambul disebut kesenian campuran (hybrid) yang dikonstruksi dari realitas sosial-budaya masyarakat urban (Cohen, 2006, pp. 2-4).

Komedi Stambul menyebar dari kota-kota di sekitar Selat Malaka, yaitu (1) dari Pontianak menyebar ke Singapura dan ke Sumatra, (2) dari Singapura ke Sumatra, dan (3) kesenian asli yang dikembangkan oleh masyarakat Sumatra (Pandji Poestaka, 12 
Juni 1924). Menurut Cohen (2001, p. 315) teater komedi muncul ketika komunitas Persia di Bombay mempelajari kesenian dan budaya Eropa. Mereka meniru berbagai bentuk kegiatan, seperti bermain kartu, belajar musik klasik, mendirikan perhimpunan kesusastraan, dan bermain drama. Dari kegiatan ini lahir kelompok drama amatir Persia Elphinstone pada 1850. Unsur-unsur teater dimodifikasi dari drama Eropa ditambahkan lagu, tari, komedi, dan sastra lokal. Perkumpulan Persia Elphinstone melakukan pertunjukan di India, kemudian berpindah-pindah tempat di daerah sekitar Selat Malaka. Hal yang sama juga dilakukan oleh Persia Curtizon dari Kalkuta.

Pertunjukan komedi dari India ditiru oleh perkumpulan lokal dengan menyajikan pertunjukan sesuai bahasa yang dikuasai oleh masyarakat. Pesan verbal diubah dan diterjemahkan dalam bahasa daerah (Cohen, 2001, pp. 315-319). Masyarakat di Sumatra dan Kalimantan membentuk tiruan kesenian yang disesuaikan dengan budaya lokal, seperti teater rakyat Abdul Muluk di Palembang dan Mamanda di Kalimantan Selatan. Tanpa mempertegas siapa yang menciptakan, kutipan berikut ini menunjukkan bahwa Komedi Stambul adalah hiburan masyarakat Melayu.

"Dari Riau toneel Melajoe itoe pindah ke Padang, dibawa oleh seorang jang bernama si Nong. Pertoendjoekan itoe disoekai benar oleh orang Padang. Tiada berapa lama mendjalarlah pertoendjoekan itoe di Soematra Barat, sehingga dengan segera djoega didapat orang-orang Padang, Pariaman, Padang Pandjang, dan tempat-tempat jang lain, jang soeka dan tjakap bermain. Tjerita jang dimainkan mereka jaitoe tjerita jang terambil dari kitab-kitab Melajoe, misalnja sjair Soeltan Abdoel Moeloek, Seri Bidasari, Selendang Delima, Sitti Zoebaidah, Ken Tamboelian, Tadjoel Moeloek, hikajat Sjah Merdan, hikajat Djohar Manikam, dll." (Pandji Poestaka, No. 24 Thn. II, 12 Juni 1924)

Teater komedi di Jawa disebut Komedi Jawa dan Wayang Cerita yang muncul pada akhir abad ke-19. Perkumpulan Komedi Jawa dibentuk oleh Raden Adipati Sutadiningrat dan Raden Bagus Jayawinata di Pandegelang pada 1875. Wayang Cerita berkembang di Bogor yang dimainkan oleh komunitas Cina pada perayaan tahun baru Cina. Masyarakat Surabaya mengenal pertunjukan komedi ketika Opera Perzie dari Bombay mengadakan pentas selama beberapa hari di alun-alun dekat Pasar Besar pada 1888. Pentas Opera Perzie lebih besar diapresiasi oleh komunitas India (Cohen, 2001, pp. 321-327). Pada 1891, Komedi Stambul dibentuk pada 1891 oleh Yap Goan Thay, A. Mahieau, dan van der Laan. Pertunjukan diselenggarakan di Kota Surabaya, kemudian berpindah-pindah tempat ke beberapa kota, seperti Mojokerto, Madiun, Surakarta, dan Semarang (Cohen, 2006, pp. 87-90). Pertunjukan Komedi Stambul ternyata tidak hanya berpindah tempat antarkota di Jawa, tetapi juga pernah tampil di Medan (Bintang Hindia, No. 1 Thn II, 1904).

Pentas Komedi Stambul dilakukan di gedung permanen dan di tanah lapang. Peralatan panggung dan tenda didesain khusus supaya mudah dibongkar dan dipindah. Ketertarikan penonton tertuju pada badut dan sri panggung (primadona). 
Penonton menyambut dengan suara gaduh, teriakan, siulan, dan riuh tepuk tangan, ketika aktor pujaan memasuki panggung. Perhatian pada seniman Komedi Stambul tidak sebatas ketika tampil di panggung pertunjukan. Kutipan berikut ini menunjukkan perhatian lebih penonton laki-laki pada aktris primadona.

\begin{abstract}
"Teroetama kaloe tiada ada badoet-badoet, stamboel keilangan banjak kekoeatannja boeat menarik penonton. Djoega sri panggoeng menarik hatinja penonton, teroetama penonton lelaki. Maski orang-orang prampoean stamboel di waktoe siang hari oemoemnja djaoeh dari pada tjantik, toch, waktoe malem dengen pertoeloengannja poepoer, dan lain-lain sebaginja, marika bisa keliatan manis sekali. [.....] Ia gila sama itoe sri panggoeng, bebrapa orang Tionghoa lain, kepalanja djoega soedah dibikin poesing oleh itoe prampoean-prampoean stamboel dan soedah borosken oeang tiada sedikit." (Pewarta Soerabaia, 16 Mei 1922)
\end{abstract}

Kutipan itu ditulis oleh seorang wartawan koran Pewarta Soerabaia yang sedang menonton sambil melakukan wawancara dengan seorang penonton Stamboel Malacca yang pentas di kawasan Kranggan. Dalam kutipan itu tampak adanya hubungan sebagian penonton laki-laki dan pemain perempuan menjalin cinta semu di luar panggung. Hubungan ini menyiratkan peran ganda pemain perempuan. Penonton Komedi Stambul datang dari berbagai latar belakang sosial dan golongan etnik, seperti Jawa, Tionghoa, Indo, dan Arab. Kehadiran Komedi Stambul merupakan wujud kreativitas yang diterima secara luas oleh segenap lapisan masyarakat dan menjadi pelopor pertunjukan komersial yang merakyat. Pertunjukan komersial Komedi Stambul di Kota Surabaya hadir dalam waktu yang hampir bersamaan dengan kemunculan kesenian Wayang Wong.

Komersialisasi Wayang Wong dimulai pada akhir abad ke-19 ketika dipentaskan di luar lingkungan istana/kraton Kasunanan. Kemunculan Wayang Wong sebagai genre kesenian diduga sudah ada sejak zaman kerajaan Majapahit yang disamakan dengan kesenian raket (Brandon, 2003, p. 67). Pada masa kerajaan Mataram, Wayang Wong menjadi salah satu bagian simbol kemegahan istana yang memiliki beberapa fungsi, di antaranya sarana hiburan, simbol legitimasi raja atau bangsawan, dan kemewahan tradisi Jawa. Hal ini tampak pada pementasan satu repertoar tidak cukup dalam waktu satu malam. Pemain wayang diperankan oleh abdi dalem dan bangsawan kraton yang khusus mengelola kesenian, sehingga tidak memiliki hubungan yang akrab dengan rakyat selama abad ke-19. Wayang Wong istana menjadi pertunjukan komersial ketika berlangsung perubahan sosial budaya di Jawa dan adanya pengaruh budaya Barat (Soedarsono, 2003, pp. 110-115). Ketika Wayang Wong menjadi kesenian komersial berarti kedudukannya tidak lagi sebagai kesenian istana, tetapi bagian dari kesenian/teater rakyat (Java Post, 8 Februari 1955).

Komersialisasi Wayang Wong istana terjadi pada 1895 yang dilakukan oleh pengusaha Cina bernama Gan Kam (Brandon, 2003, p. 71; Soedarsono, 2003, pp. 112113). Perkumpulan Wayang Wong lain sudah mengadakan pertunjukan di Batavia 
pada tahun 1890. Wayang Wong dari Solo yang dipimpin oleh Ong An Hoang juga pentas di Kota Surabaya pada Juni 1891, kemudian dilanjutkan oleh Bambang Langen Koesoemo pada Agustus 1891 (Cohen, 2001, p. 326). Dengan demikian, pertunjukan komersial Wayang Wong telah dikenal oleh masyarakat Surabaya bersamaan dengan lahirnya Komedi Stambul. Pada awal abad ke-20, popularitas Wayang Wong telah menyebarluas di seluruh lapisan masyarakat. Hal ini yang mendorong munculnya inisiatif pembentukan perkumpulan Wayang Wong profesional dan amatir (Java Post, 8 Februari 1955). Contohnya adalah Wayang Wong profesional yang dibentuk di Kampung Grudo oleh orang Cina pada awal abad ke-20. Bekas pabrik beras di Grudo dimanfaatkan untuk menyelenggarakan pentas (Bintang Soerabaia, 12 April 1904). Perkumpulan Wayang Wong lain juga muncul, yakni Langen Hesti Budoyo di Ketabang yang dipimpin oleh Raden Mertodiwirjo (Bintang Soerabaia, 28 April 1904). Contoh lain adalah Wayang Wong amatir yang dibentuk oleh J. Schoelten dengan pemain terdiri atas sekelompok murid. Perkumpulan ini mengadakan pertunjukan di Gedung Kesenian (Schouwburg) dan Kebun Raja (Stadstuin) untuk penggalangan dana (Pewarta Soerabaia, 11 Juli 1916).

Pentas diadakan di tempat semipermanen dan permanen selama beberapa hari atas inisiatif sendiri atau undangan perorangan dan organisasi sosial (Bintang Soerabaia, 4 Juli \& 20 Agustus 1912). Penonton utama berasal dari komunitas Jawa. Hal ini terkait dengan dialog pertunjukan menggunakan bahasa Jawa halus (Jawa Krama) yang hanya dipahami oleh orang Jawa. Seperti pertunjukan panggung Komedi Stambul, pemain utama (primadona) selalu mendapat sambutan (Bintang Soerabaia, 13 Januari 1904). Kehadiran Komedi Stambul dan Wayang Wong menunjukkan realitas hiburan kota selama paruh pertama abad ke-20. Keberadaannya ibarat ungkapan "patah tumbuh hilang berganti". Wayang Wong selalu hadir di tengah masyarakat, baik perkumpulan yang dibentuk di Kota Surabaya, misalnya Wayang Wong Saritomo, maupun perkumpulan dari kota lain, misalnya Ngesti Pandowo dari Semarang, memilih Kota Surabaya tujuan pentas pada 1930-an (Panjebar Semangat, No. 16, 17 Desember 1938; No. 45 \& 46, 6 \& 13 Juli 1940).

Kreativitas berkesenian masyarakat tidak padam meskipun selama pendudukan Jepang dan masa kemerdekaan karena kondisi sosial, ekonomi, dan politik tidak stabil. Kreativitas masyarakat Surabaya terlihat lagi ketika Wayang Wong Langen Sedya Rahayu dirintis oleh Soeradi pada 1948 (AKS, No. 34.786 Box 2041). Komedi Stambul dan Wayang Wong telah mengakar sebagai hiburan masyarakat Surabaya pada awal abad XX, tetapi bukan representasi identitas seni-budaya Surabaya.

\section{Ruang Pertunjukan Teater Komersial}

Pentas teater komersial diselenggarakan berdasar inisiatif perkumpulan, undangan perorangan untuk memeriahkan pesta (kelahiran, khitanan, dan pernikahan), dan undangan organisasi sosial untuk memeringati hari kelahiran atau penggalangan dana. Pertunjukan secara rutin juga diselenggarakan secara reguler di kegiatan 
pameran kolonial dan pasar malam. Ketika kegiatan ritual selamatan kampung, berbagai jenis kesenian tampil di kampung-kampung.

\title{
Pameran Kolonial
}

Pasar malam dan jaarmarkt menjadi ruang bagi Komedi Stambul, Wayang Wong, dan Ludruk menghibur masyarakat. Pameran jaarmarkt pertama diselenggarakan pada 1417 Mei 1905 di Taman Kota (Stadstuin) (von Faber, 1930: 14), yang berlanjut setiap tahun sekali sampai 1939. Secara harafiah jaarmarkt artinya aktivitas pasar yang dikemas dalam wujud pameran (tentoonstelling). Pameran digunakan sebagai strategi ekonomi pemasaran melalui kombinasi kegiatan perdagangan dan waktu senggang. Beberapa jenis produk kerajinan didatangkan dari berbagai daerah di Hindia Belanda (Jaspers, 1908: 4-7). Agenda pemasaran dimeriahkan oleh berbagai jenis hiburan, seperti pertunjukan kesenian rakyat (Wayang Wong dan Ludruk), pemutaran gambar idoep, musik, dan lomba memanah (Jaspers, 1908: 4-7). Melalui ruang pameran, kesenian Ludruk semakin dikenal oleh masyarakat.

\begin{abstract}
"Banjak orang di tempat pertoendjoekan itoe, boekan sadja terdapat berbagai pekerjaan haloes jang ditanding, tetapi djoega berbagai permainan, seperti Gamelan, Wajang Koelit, Gamboeh, Gandroeng Bali, dan Loedroekan." (Bintang Hindia, No. 17 Thn III, 1905)
\end{abstract}



Gambar 1. Pengunjung Jaarmarkt, 6-13 Mei 1906.

Sumber: Bintang Hindia, No. 14 Thn. IV, 1 November 1906.

Pada Gambar 1 tampak pengunjung berpakaian rapi dan necis berjalan di depan pintu gerbang yang dihias umbul-umbul, bendera Belanda, dan terlihat "keramaian ini didatangi oleh boemipoetra, baik laki-laki ataoe perempoean, toea dan moeda, semoeanja datanglah ke tempat keramaian itoe." (Bintang Hindia, No. 14 Thn IV, 1 November 1906). Menurut laporan J. E. Jaspers (1908: 3\&7) diketahui bahwa pameran dikunjungi oleh masyarakat yang tinggal di Kota Surabaya tanpa membedakan status sosial, bahkan ada yang datang dari beberapa daerah di Jawa Timur secara 
rombongan, misalnya para bupati dan kepala distrik, murid-murid sekolah pendidikan guru (kweekschool) dari Probolinggo dan Mojowarno, murid-murid sekolah Bumiputra dan Eropa. Tarif masuk ditetapkan sebesar f. 0,5 untuk orang Eropa dan Timur Asing dan f. 0,1 untuk Bumiputra.

Pada jaarmarkt periode kedua yang dimulai pada 1923 di lapangan Ketabang, jenis hiburan tidak hanya kesenian, tetapi juga pertandingan sepak bola, tenis, tinju, basket, anggar, atletik, atraksi ketangkasan mengendarai sepeda motor dan mobil, dan karapan sapi (Pewarta Soerabaia, 27 April \& 28 Juli 1923). Atraksi harian (dagelijksche attracties) berupa pentas seni pertunjukan, seperti Wayang Wong, Ludruk, Komedi Stambul, Musik, dan Sulapan (Viribus Unitis, 4e Jaargang No. 8, Agustus 1923; De Indische Courant, 17 Juli 1923). Beberapa seni pertunjukan dari luar Kota Surabaya yang tampil adalah Tandhak dan Gandrung Bali, Kecapi, Ketuk Tilu, Ogleng Bandung, Kroncong Kediri dan Semarang, Wayang Cokek Betawi, Sandur Madura, dan Reog Ponorogo (Bintang Soerabaia, 2 Juli \& 1 Agustus 1921; De Indische Courant, 17 Juli 1923; Pewarta Soerabaia, 30 Juli 1923). Permainan dan seni pertunjukan menjadi bagian yang menyatu dengan pameran. Agenda rutin pameran menjadi peristiwa penting dan berkala dalam kalender kolonial (Mrazek, 2006, p. 67). Pameran menjadi sarana komersial, promosi, dan sosialisasi kesenian. Penggabungan kegiatan ekonomi dan kesenian menandakan perkembangan industri budaya pada awal abad ke-20. Dengan demikian, wacana yang muncul akhir-akhir ini tentang industri budaya sesungguhnya akarnya telah tumbuh pada awal abad ke-20, yakni dalam industri budaya yang dijual adalah jasa dan peristiwa.

Pameran kolonial membuktikan bahwa kegiatan ini menjual barang kebutuhan sehari-hari dan peristiwa. Masyarakat secara gencar dipengaruhi melalui publikasi di surat kabar dengan penekanan pameran sebagai bagian dari peristiwa budaya. Pengunjung yang berlatar belakang dari pekerja rendahan, hanya dengan berbekal uang sebesar $f$. 1,00 dapat menikmati tontonan atau sekadar melihat-lihat barang pajangan (Jaspers, 1908: 3). Pameran direncanakan dan dirancang dengan persiapan yang baik. Pencantuman jadwal kegiatan dan pemberitaan selalu mengandung kalimat persuasif, misalnya pameran hanya dapat ditonton sekali setahun yang disampaikan secara berulang-ulang (Medan Prijaji, No. 26 Thn III, 1909; Pewarta Soerabaia, 8 Mei 1914). Ketika tiba waktunya, terbukti bahwa pameran menjadi pusat keramaian, karnaval, kirab, pesta, dan berbagai suguhan hiburan berbagai jenis kesenian. Pameran dapat menguatkan (affirmation) solidaritas, mengintegrasikan masyarakat, mengembangkan budaya kerakyatan, dan menumbuhkan kesenian rakyat.

\section{Kegiatan Ritual Masyarakat Kampung}

Kesenian Ludruk menjadi identitas budaya masyarakat Kota Surabaya ketika selalu dilibatkan memeriahkan kegiatan ritual masyarakat kampung. Aktivitas ritual diselenggarakan secara perorangan dan komunal dalam bentuk slametan. Ritual slametan menyangkut ritus pribadi tampak pada kelahiran, khitanan, pernikahan, dan kematian, sedangkan ritual komunal berhubungan dengan perayaan keagamaan dan 
slametan kampung. Prosesi slametan kampung bertujuan memohon keselamatan kampung dari bahaya dan bencana yang tidak diduga. Ritual ini juga disebut sedekah bumi yang dikemas sebagai pesta kampung. Penduduk kampung menikmati makanan dan minuman bersama-sama. Beraneka jenis makanan yang akrab dinikmati sehari-hari oleh masyarakat kampung dihidangkan, seperti tampak pada Gambar 2.

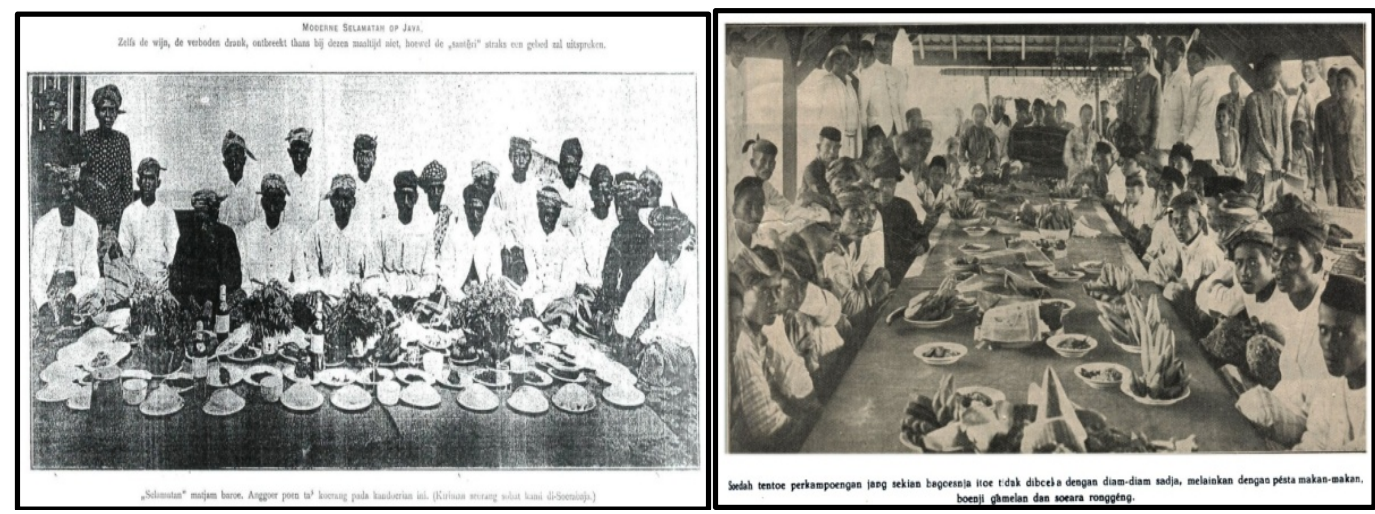

Gambar 2. Aktivitas Slametan di Kampung

Sumber: Bintang Hindia, No. 1 Thn II, 1904, hlm. 4 (kiri); Pandji Poestaka, Nomor 55 Tahun VII, 9 Juli 1929, hlm. 869 (kanan).

Gambar 2 (kiri) tertera keterangan, "Selamatan matjam baroe. Anggoer poen $\mathrm{ta}^{\prime}$ koerang pada kandoerian ini." (Bintang Hindia, No. 1 Thn II, 1904), sedangkan gambar sebelah kanan tertera keterangan, "Soedah tentoe jang sekian bagoesnja itoe tidak diboeka dengan diam-diam sadja, melainkan dengan pesta makan-makan, boenji gamelan, dan soeara ronggeng." (Pandji Poestaka, No. 55 Thn VII, 9 Juli 1929). Ritual slametan kampung merupakan kegiatan pesta makanan dan hiburan yang mengandung aspek religi, kebersamaan (gotong royong), dan kerukunan masyarakat. Kegiatan slametan digunakan sebagai media penghubung alam nyata dan gaib. Praktik ini sudah lama mengakar dalam kehidupan masyarakat Jawa. Nilai kebersamaan dan kerukunan ditunjukkan oleh masyarakat kampung ketika mereka mengumpulkan dana untuk membiayai kegiatan hiburan (Bintang Soerabaia, 24 \& 25 Mei 1904). Berikut ini contoh dua kampung mengadakan hiburan dalam rangka Sedekah Bumi. Kampung Pregolan menyelenggarakan kesenian Tayub dan Ludruk, sedangkan Kampung Semampir menyelenggarakan Wayang Kulit dan Tayuban (Tandhakan).

\footnotetext{
"Orang pendoedoek di kampoeng Pregolan nanti sedikit hari bakal membikin slametan sidekah boemi dengen pake tajoeban dan loedroekan sebagi biasanja saben tahoen sekali katanja nanti teropnja hendak diatoernja jang lebih elok dari jang soeda soeda." (Bintang Soerabaia, 24 Mei 1904)

"Soeda tamtoe nanti malem Minggoe tanggal 28 Mei 1904 di mana kampoeng Semampir ada slametan sidekah boemi dengen wajangan lakonnja Brontojoedo, ja itoe oeran oeran Djojobinangoen dan besoek paginja teroes plesiran tandakan dari ini satoe kampoeng soeda masoehoer rameenja kaloe sidekah boemi sebab loerah nja amat accoord sama orangnja." (Bintang Soerabaia, 25 Mei 1904)
} 
Masyarakat kampung mengadakan pesta hiburan Wayang Kulit, Tayuban, dan Ludruk, sesuai kesepakatan. Warga kampung yang tidak menyelenggarakan hiburan dapat bergabung menikmati tontonan di kampung lain (Bintang Soerabaia, 4, 24, \& 25 Mei 1904). Meskipun tidak jelas kapan tradisi ini dimulai, kebiasaan slametan diduga sebagai perpaduan antara ritual Hindu dan Islam yang terbukti menjadi fasilitas menumbuhkan dan menyuburkan kesenian Ludruk di Kota Surabaya.

\section{Kesenian Ludruk sebagai Identitas Budaya Kota Surabaya}

Pertunjukan teatrikal yang merepresentasikan identitas budaya masyarakat Kota Surabaya bukan pada Stambul dan Wayang Wong, tetapi pada kesenian Ludruk. Konteks sosiokultural kesenian Ludruk menunjukkan cerminan budaya Arek Surabaya (Frederick, 1989: 83). Ludruk Sandiwara merupakan bentuk baru seni teater. Perubahan dari Besutan ke Ludruk Sandiwara ditunjukkan dari penambahan tampilan busana. Pemain Besutan memakai kopiah Turki, berkain putih, ikat pinggang dari lawe, sedangkan busana Ludruk Sandiwara telah dilengkapi berbagai aksesoris baru sesuai zaman. Unsur cerita tidak lagi seperti Besutan, tetapi mengambil lakon-lakon drama modern (Anonim, 1953: 852). Popularitasnya semakin meluas pada 1930 karena dikoordinasikan dengan baik oleh seniman yang tergabung dalam perkumpulan.

Menurut kesaksian Sujanto Abdulmadjid, para seniman yang berkontribusi pada perubahan struktur Ludruk adalah Durasim Gondoredjo (Gondo Durasim), Kusen, Ngari, Amir, Minin, Ratno, Satari, dan Wakidin, sebagai tokoh-tokoh perintis Ludruk Sandiwara (Pewarta Soerabaia, 30 November 1950). Durasim Gondoredjo adalah seniman fenomenal yang memiliki sikap kritis sejak 1928 ketika menjalin persahabatan dengan tokoh pergerakan dokter Soetomo yang bermukim di Kota Surabaya sejak 1923. Persahabatan ini dianggap sebagai hubungan dua tokoh yang berlatar belakang berbeda, tetapi dapat saling mengisi kekurangan. Dokter Soetomo tertarik pada karya, gagasan, kemampuan, dan keberanian Durasim Gondoredjo mengkritik pemerintah kota secara terbuka pada saat berperan sebagai badut (Frederick, 1989: 84). Interaksi ini menghasilkan perkumpulan Ludruk Organisatie sejak awal tahun 1930-an. Sejak saat itu, perkumpulan Ludruk Trisno Enggal menyusul didirikan pada 1932 dipimpin oleh Klowor. Keterangan diberikan oleh Abd Manap selaku sekretaris Ludruk Tresno Enggal ketika memberi keterangan pers mengenai pemutusan siaran di RRI Surabaya (Suara Masjarakat, 27 Februari 1956)

Perkumpulan Ludruk yang dipimpin oleh Durasim Gondoredjo pentas di Kota Surabaya dan nobong di kota-kota lain di Jawa Timur. Pada waktu mengadakan pertunjukan di Jombang, seluruh pemain Ludruk ditangkap dan dibawa ke Surabaya. Mereka diinterogasi oleh anggota kempetai (polisi militer Jepang) hingga menyisakan tujuh orang tetap ditahan, yaitu Gondo Durasim, Amir, Satari, Kemiso, Wakidin, Karso, dan Kamidi, karena dianggap bertanggung jawab atas kidungan (syair/pantun) pegupon omahe doro, melu nippon tambah soro (Pegupon rumah burung merpati, mengikuti Jepang tambah sengsara) yang disampaikan dalam setiap pentas. Kidungan ini dianggap sebagai agitasi politik. Tahanan mengalami penyiksaan yang 
menyebabkan kesehatan Durasim menurun dan meninggal (Obor Surabaja, 8 Januari 1952; Mutiara, No. 323, 20 Juni-3 Juli 1984; Bende, 7 November 2003).

Jasad Gondo Durasim atau Durasim Gondoredjo dimakamkan di pemakaman Tembok. Di pusara makam dibangun patung setengah badan sebagai monumen pengenang tokoh kesenian Ludruk. Durasim Gondoredjo lahir pada hari Rabu Wage tanggal 11 Januari 1888 (Perdamaian, 16 Desember 1956). Peristiwa penangkapan seniman Ludruk membuktikan kegagalan propaganda pemerintah pendudukan Jepang memanfaatkan kesenian Ludruk. Kurasawa $(1993,246)$ menyatakan bahwa rezim penguasa memanfaatkan popularitas kesenian rakyat sebagai media propaganda dan mobilisasi untuk kepentingan perang. Realitasnya justru berbalik, perkumpulan Ludruk menyerang pemerintah pendudukan Jepang melalui kritikankritikan dalam kidung.

Penyebarkan semangat nasionalisme melalui pertunjukan merupakan tindakan perlawanan pada masa pendudukan Jepang dan perjuangan kemerdekaan. Kesenian Ludruk berfungsi ganda sebagai hiburan, media perjuangan, dan penerangan kepada masyarakat. Aksi perjuangan seniman Ludruk dilakukan dengan cara menghimpun dana untuk membantu perang. Salah satu perkumpulan Ludruk yang berkontribusi seperti yang diberitakan dalam Soeara Asia, tanpa disebutkan nama rombongannya, mengadakan pertunjukan pada bulan November 1943. Uang yang terkumpul diberikan pada Cogni dan korban bom, masing-masing sebesar 25\% dan sisanya untuk tentara Pembela Tanah Air (PETA) (Soeara Asia, 19 November 1943). Pada kesempatan yang lain perkumpulan Ludruk Moeljo Sedjati juga mengadakan pentas untuk mengumpulkan dana yang seluruhnya disalurkan pada tentara PETA (Soeara Asia, 26 November 1943).

Kebersamaan dan kerja sama dilakukan selama masa perang kemerdekaan. Beberapa perkumpulan, seperti Ludruk Marhaen, Tresno Enggal, Saritomo, dan Ludruk Jawa Timur, melebur menjadi Ludruk Sekar Mulya. Penggabungan ini dikoordinasi oleh Ludruk Marhaen. Ketika kondisi politik, keamanan, dan ketertiban stabil sejak pengakuan kedaulatan negara, perkumpulan Ludruk yang tergabung dalam Ludruk Sekar Mulya mulai memisahkan diri untuk memulihkan perkumpulan seperti sebelumnya (Mimbar Kotapraja Pasuruan, No. 3/4 Maret 1957; Anonim, 1953, p. 854). Bahkan, sebagian anggota Ludruk Aliran Massa memisahkan diri untuk membentuk Ludruk Warna Warni yang dipimpin oleh Sipoean dan Warna Sari yang dipimpin oleh Kastamin. Jumlah perkumpulan Ludruk yang bertambah memicu persaingan untuk dekat dengan masyarakat. Supaya tidak terjadi persaingan yang merugikan, beberapa perwakilan Ludruk, seperti Aliran Massa, Warna Sari, Marhaen, Tresno Enggal, dan Jawa Timur, mengadakan pertemuan pada 26 Februari 1952 yang dipimpin oleh Bowo dari Marhaen. Pertemuan itu bertempat di rumah Kasian di kampung Genteng Bandar. Kesepakatan yang dihasilkan adalah mencegah persaingan dan perebutan seniman-seniman Ludruk. Dari pertemuan ini terbentuk organisasi kesenian Ludruk yang disebut Persatuan Sandiwara Ludruk (Persalu) yang beranggotakan tujuh perkumpulan Ludruk (Pewarta Soerabaia, 28 Februari 1952; Java Post, 15 Maret 1952). Jumlah anggota organisasi ini bertambah menjadi 12 pada Juli 1953, sedangkan jumlah 
keseluruhan sebanyak 48 perkumpulan (Pewarta Soerabaia, 14 Maret 1953; Trompet Masjarakat, 20 Juli 1953).

Perjalanan kesenian Ludruk menegaskan kesenian ini lahir dan berkembang pesat di Surabaya. Ibarat sebuah keluarga, kesenian Ludruk adalah anak kandung masyarakat Surabaya, sedangkan kesenian teater lain adalah anak angkat yang dipungut dari keluarga lain. Hanya anak kandung yang mewarisi genetik dari orang tuanya. Analogi ini dapat dilihat dari pemakaian dialog. Dialog dalam pentas Ludruk merupakan salah satu pencerminan cara komunikasi masyarakat Surabaya. Masyarakat Surabaya dalam komunikasi sehari-hari menggunakan bahasa Jawa dialek Surabaya, demikian juga dengan bahasa pengantar Ludruk. Hal ini tentu saja tidak terjadi pada Komedi Stamboel, Wayang Wong, dan Kethoprak. Pada 1950-an, muncul gagasan memodifikasi pertunjukan Ludruk mengikuti perkembangan zaman, tetapi satu unsur yang ditolak untuk dimodifikasi adalah penggunaan bahasa. Bahasa dialek Surabaya merupakan karakteristik kesenian Ludruk (Pewarta Soerabaia, 30 November 1950).

Karakteristik lain yang menunjukkan identitas budaya tampak pada struktur pertunjukan, yaitu tari Ngremo, atraksi bedhayan (tandhakan), dhagelan atau lawakan, dan penyajian lakon (cerita). Tari Ngremo atau Tandhakan ditampilkan sebagai pembukaan pertunjukan yang dimainkan oleh laki-laki memakai kostum prajurit dan laki-laki yang menyamar sebagai perempuan. Tarian ini merupakan kreasi yang diadopsi dari kesenian yang digemari masyarakat Surabaya, yaitu Tayuban atau Tandhakan. Daya tarik perempuan seniman (transvestite) tampak pada kecantikan di atas panggung dengan gerakan tari yang memiliki konotasi erotis sebagai simbol seksual pemikat penonton agar terlibat secara emosional dalam pertunjukan Ludruk (Peacock, 1967, p. 235).

Dhagelan muncul setelah tarian selesai dengan teknik kidungan, monolog, dan dialog yang mengungkapkan secara satire mengenai realitas sosial dan berusaha membuat penonton tertawa. Pakaian, cara bersikap, dan bahasa yang digunakan oleh pelawak menunjukkan kelas pekerja (Peacock, 2005 p. 60). Tokoh dhagelan menampilkan identitas penonton di atas panggung. Alur cerita diperagakan oleh beberapa pemain yang disesuaikan dengan karakter cerita. Lakon (repertoar) yang disampaikan umumnya cerminan kehidupan sosial masyarakat Kota Surabaya. Lakon Ludruk dibedakan menjadi dua, yaitu: (1) cerita pakem, seperti Lakon Cak Sakera dan Lakon Sarif Tambak Yoso; (2) Cerita rekaan, yaitu cerita yang ditulis oleh pengarang naskah. Para penonton menganggap tokoh dhagelan menampilkan identitas mereka di atas panggung.

Kesenian Ludruk menunjukkan kekhasan budaya yang mampu memainkan realitas kehidupan kampung dalam panggung pertunjukan. Pada awal abad ke-20, Ludruk yang juga disebut Besutan merupakan bagian yang menyatu dengan kebiasaan atau tradisi masyarakat dalam aktivitas slametan (Peacock, 1968, p. 331). Koran Bintang Soerabaia mencatat bahwa aktivitas slametan dan kesenian (Tayuban, Wayangan, dan Ludrukan) merupakan dua hal yang berbeda tetapi saling melengkapi. 
"Orang pendoedoek di kampoeng Pregolan nanti sedikit hari bakal membikin slametan sidekah boemi dengen pake tajoeban dan loedroekan sebagi biasanja saben tahoen sekali katanja nanti teropnja hendak diatoernja jang lebih elok dari jang soeda soeda." (Bintang Soerabaia, 24 Mei 1904)

Menurut Peacock, Ludruk menjadi pelengkap bagi ritus bersih desa (sedekah bumi) dan slametan yang disebut sebagai ritus penyatuan. Mereka menyucikan kampung atau lingkungan dalam kampong (Peacock, 2005, 219). Meskipun kesenian Ludruk dan slametan berbeda, secara teoretis bahwa slametan dianggap ritus penyatuan (rite of incorporation) dan Ludruk dianggap ritus pemisahan (rite of separation), relasi antara penduduk kampung dan kesenian Ludruk layak disebut relasi simbiosis mutualistik. Kesenian Ludruk membutuhkan penonton, yang sebagian besar datang dari penduduk kampung, dan penduduk kampung sendiri membutuhkan hiburan yang sesuai dengan identitas budaya mereka.

\section{Simpulan}

Pertunjukan komersial dalam bentuk kesenian sandiwara modern masih menjadi bagian eksklusif kelompok Eropa pada abad ke-19. Kesenian ini dianggap tidak mencerminkan budaya mayoritas masyarakat, sehingga lahir kesenian komersial yang bersumber dari tradisi, seperti Komedi Stambul, Wayang Wong, Kethoprak, dan Ludruk. Arena pameran merupakan dunia milik bersama yang digunakan sebagai sarana menghabiskan waktu senggang sekaligus berkontribusi mempopulerkan teater tradisi. Realitas ini merupakan transformasi ruang yang menandakan era baru budaya masyarakat kota. Pameran telah menjadi tradisi masyarakat yang mampu menumbuhkan atau mengangkat budaya lokal sebagai identitas budaya. Hal ini tampak pada kesenian rakyat yang sederhana, kemudian berubah menjadi sarana hiburan komersial ketika mendapatkan sentuhan kreatif. Orientasi masyarakat terhadap teater tradisi dapat disalurkan melalui momentum ritus tertentu, seperti kelahiran, khitanan, pernikahan, dan ritual slametan kampung.

Dari gejala lahirnya pertunjukan komersial ditemukan bahwa identitas senibudaya masyarakat Kota Surabaya teraktualisasi dan teridentifikasi dengan jelas ketika terlibat dalam kegiatan budaya yang diselenggarakan oleh masyarakat kampung. Perwujudan identitas seni-budaya masyarakat Kota Surabaya terdapat pada kesenian Ludruk. Kesenian Ludruk menampilkan kehidupan masyarakat Surabaya di atas panggung yang mencerminkan keseharian masyarakat kampung. Bagi masyarakat kampung, panggung kesenian Ludruk menampilkan diri mereka, yaitu kelompok masyarakat dengan kebiasaan dan gaya hidup kampung. Realitas ini menunjukkan kesenian Ludruk adalah identitas budaya masyarakat kota khususnya kelompok masyarakat menyandang identitas khas Arek Suroboyo. Tantangan yang dihadapi akhir-akhir ini adalah adanya sentuhan budaya baru yang menggerus budaya lokal (kesenian tradisi), peralihan media hiburan, berkurangnya keterlibatan masyarakat pendukung, dan regenerasi yang terputus. 


\section{Referensi}

Ahimsa-Putra, Heddy Shri (2000). Wacana seni dalam antropologi budaya: Tekstual, kontekstual, dan post-modernitas. Dalam H. S. Ahimsa-Putra (Ed). Ketika orang Jawa nyeni. Yogyakarta: Galang Press.

Anonim (1953). Propinsi Jawa Timur 1950. Surabaya: Jawatan Penerangan RI

Bende, 7 November 2003.

Bintang Hindia, No. 1 Thn. II, 1904.

Bintang Hindia, No. 14 Thn. IV, 1 November 1906.

Bintang Hindia, No. 17 Thn. III, 1905.

Bintang Soerabaia, 1 Agustus 1921.

Bintang Soerabaia, 12 April 1904.

Bintang Soerabaia, 13 Januari 1904.

Bintang Soerabaia, 2 Juli 1921.

Bintang Soerabaia, 20 Agustus 1912.

Bintang Soerabaia, 21 Maret 1904.

Bintang Soerabaia, 24 Mei 1904.

Bintang Soerabaia, 28 April 1904.

Bintang Soerabaia, 28 Mei 1904.

Bintang Soerabaia, 4 April 1904.

Bintang Soerabaia, 4 Juli 1921.

Brandon, J. R. (2003). Jejak-jejak seni pertunjukan di Asia Tenggara. Bandung: P4ST.

Cohen, M. I. (2006). The komedie stamboel: popular theater in colonial Indonesia, 1891-1903. Athens: Ohio University Press.

Cohen, Matthew Isaac (2001). On the origin of the komedie stamboel popular culture, colonial society, and the parsi theatre movement. Bijdragen tot de Taal-, Land-en Volkenkunde, 157 (2): 313-357.

De Indische Courant, 17 Juli 1923.

Frederick, W. H. (1989). Pandangan dan gejolak: Masyarakat kota dan lahirnya revolusi Indonesia (Surabaya 1926-1946), terj. Hermawan Sulistyo. Jakarta: Gramedia.

Jaspers, J. E. (1908). Verslag van de derde jaarmarkt-tentoonstelling te Soerabaja. Batavia: Landsdrukkerij.

Java Post, 15 Maret 1952.

Kayam, Umar (1981). Seni, tradisi, masyarakat. Jakarta: Sinar Harapan.

Kurasawa, Aiko (1993). Mobilisasi dan kontrol: Studi tentang perubahan sosial di pedesaan Jawa 1942-1945. Jakarta: Gramedia Widiasarana.

Mimbar Kotapraja Pasuruan Nomor 3/4, Maret 1957.

Mrazek, Rudolf (2006). Engineers of happy land, perkembangan teknologi dan nasionalisme di sebuah koloni. Jakarta: Yayasan Obor Indonesia.

Pandji Poestaka, No. 24 Thn. II, 12 Juni 1924.

Pandji Poestaka, No. 55 Thn. VII, 9 Juli 1929.

Panjebar Semangat, No. 16, Thn. VI, 17 Desember 1938.

Panjebar Semangat, No. 45, Thn. VII, 6 Juli 1940.

Panjebar Semangat, No. 46, Thn. VII 13 Juli 1940. 
Peacock, James L. (1967). Comedy and centralization in Java: The ludruk plays", The Journal of American Folklore, 80 (318): 345-356.

Peacock, James L. (1968). Ritual, entertainment, and modernization: A Javanese. Comparative Studies in Society and History, 10 (3): 328-384.

Peacock, James L. (2005). Ritus modernisasi: Aspek sosial dan simbolik teater rakyat Indonesia, terjemahan Eko Prasetyo. Jakarta: Desantara.

Perdamaian, 16 Desember 1956.

Pewarta Soerabaia, 11 Juli 1916.

Pewarta Soerabaia, 14 Maret 1953.

Pewarta Soerabaia, 16 Mei 1922.

Pewarta Soerabaia, 27 April 1923.

Pewarta Soerabaia, 28 Februari 1952.

Pewarta Soerabaia, 28 Juli 1923.

Pewarta Soerabaia, 30 Juli 1923.

Pewarta Soerabaia, 8 Mei 1914.

Pisani, J. A. (2004). "Globalisation and cultural transformation: African and South African perspectives". International Area Review. 7(1): 37-62.

Raffles, T. S. (2008). The history of Java. Yogyakarta: Narasi.

"Keluar Masuk Penjara Akibat Main Ludruk," Mutiara, No. 323. 20 Juni-3 Juli 1984.

Rosenmann, Amir, Gerhard Reese, and James E. Cameron (2016). Social identities in a globalized world: Challenges and opportunities for collective action. Perspectives on Psychological Science, 11(2): 202-221.

Soeara Asia, 19 November 1943.

Soeara Asia, 26 November 1943.

Soedarsono, R. M. (2003). Seni pertunjukan dari perspektif politik, sosial, dan ekonomi. Yogyakarta: Gadjah Mada University Press.

Suara Masjarakat, 27 Februari 1956.

Trompet Masjarakat, 20 Juli 1953.

von Faber, G. H. (1930). A short history of journalism in the Dutch East Indies. Surabaya: G. Kolff \& Company.

von Faber, G. H. (1931). Oud Soerabaia: de geschiedenis van Indie's eerste koopstad van de oudste tijden tot de Instelling van gemeenteraad 1906. Soerabaia: Gemeente Soerabaia.

"9e Jaarmarkt Tentoonstelling," Viribus Unitis, 4e Jaargang No. 8, Agustus 1923.

"Den Hoofdambtenaren voor Gemeentenzaken Hoofd van het Kantoor voor Bevolkingszaken," dalam Arsip Kota Surabaya, No. 34.786 Box 2041.

"Di Belakang Layar Sandiwara: Ludrug Kesenian Arek Surabaja, Asal-Usul Ludrug," Obor Surabaja, 8 Januari 1952.

"Hari kemudian seni drama tari wajang-orang" dalam Java Post, 8 Februari 1955.

"Pasar Malam ka 5 di Soerabaia dari Hari Minggoe 1 Augustus sampai Hari Selasa 10 Augustus 1909", Medan Prijaji, No. 26 Thn III, 1909.

"Tjerita, Tata Bahasa, Tingkah-Laku, akan Mempertinggi Kesenian Daerah," Pewarta Soerabaia, 30 November 1950. 